\title{
PEACEBUILDING PRACTICES OF JAPAN: LESSONS FROM SRI LANKA
}

\author{
Nirmali Wijegoonawardana ${ }^{* 1}$ 可 \\ ${ }^{* 1}$ Senior Lecturer, University of Colombo Sri Lanka
}

DOI: https://doi.org/10.29121/granthaalayah.v8.i10.2020.1527

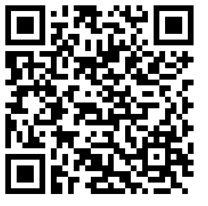

Article Type: Research Article

Article Citation: Nirmali

Wijegoonawardana. (2020).

PEACEBUILDING PRACTICES OF

JAPAN: LESSONS FROM SRI LANKA.

International Journal of Research -

GRANTHAALAYAH, 8(10), 21-30.

https://doi.org/10.29121/granthaa

layah.v8.i10.2020.1527

Received Date: 11 September 2020

Accepted Date: 22 October 2020

Keywords:

Peace Process

Post-conflict Society

Reconciliation

Peacebuilding

Japan and Sri Lanka

\section{ABSTRACT}

Peacebuilding involves a process that includes different roles and functions. It also ranges from a series of activities such as ceasefire and refugee resettlement to the development of revised economic reconstruction and a new government. International communities have significantly increased aid for prevention of conflict, rapid humanitarian aid and reconstruction in post-conflict zones. In the wide spectrum of peacebuilding, the Government of Japan which had been certain to dedicate to traditional development issues widened the activities beyond the development after 2002. That was the time to respond to the Sri Lanka conflict with the Japan's policy on Consolidation of Peace. The aim of this paper is to examine the peacebuilding efforts of the Japanese government since 2002 in post-conflict Sri Lanka. The study adopts a descriptive nature through the use of a qualitative method. This paper will also scale the effectiveness of the Japanese peacebuilding efforts in Sri Lanka.

\section{INTRODUCTION}

Peacebuilding is a multi- element process in the post- conflict society. Therefore, it is difficult to define and in practice even harder to create (Cousens et al., 2001). Some elements in peacebuilding may have contrasted each other in absolute objectives, ways, and others. Persons attempting to reconstruct the affected society are encumbered with an uncomfortable choice owing to the prevailing conflict and the simultaneous promotion of democracy and state-building (Fukayamya, 2005).

How does appropriate peacebuilding grow in a post-conflict setting for the state and communities in the wide range of its scales? Since the increased recurrence of civil conflicts and humanitarian problems in the world, Japanese peacebuilding efforts have been very significant to meet the increasing demand of international contributions for peacebuilding. Since then Japan has created an effective peacebuilding initiative in responding to appeals of international cooperation. Japan has provided very significant support in Sri Lanka's journey of peacebuilding efforts.

The objective of this paper is to examine the Japanese government's efforts to peacebuilding in Sri Lanka since 2002, as a new type of peacebuilding which tried to accept the state-oriented ownership in the process. As a research note, this paper will first review the overall view of Japan's peacebuilding diplomacy and, second, examine Japan's

(C) 2020 The Author(s). This is an open access article distributed under the terms of the Creative Commons Attribution License, which permits unrestricted use, distribution, and reproduction in any medium, provided the original author and source are credited. 
peacebuilding projects and programs in Sri Lanka. Finally, this paper concludes effectiveness of Japan's practical efforts to build peace in Sri Lanka. This descriptive work will contribute to revitalize a further discussion of the rudimental effort of Japanese Government to the conflict area, by updating academic awareness to the accepted peacebuilding by Sri Lanka.

A qualitative methodology and a descriptive nature are used in the study. The method of collecting data will be from official publications, policy documents, program reports, official statements and diplomatic Blue books, and secondary data will be to obtain by reviewing the existing literature.

\section{CONCEPT OF PEACEBUILDING}

The concept of peacebuilding became one of the tools for conflict management in internal conflicts such as civil wars and ethnic and religious struggles that often flared up in the post- Cold War era throughout world. In 1992, Boutrous Boutrous Ghali, the United Nations Security General, issued an official document, the Agenda for Peace, proposing a phased approach to addressing such conflicts through preventive diplomacy, peace building, peacekeeping, peacekeeping and post- war peace building. In 2000, the United Nations (UN) Peace Operations Panel issued the Brahimi Report on enhancing the efficiency of peace building. The report broadened the definition of peacebuilding through the prospect of assisting communities and nations in the transition from war to peace and recognizing the key role of building peace in complex peace operation (Brahimi Report, 2000). The report also incorporated the importance of disarmament, demobilization and reintegration (DDR) and considered statebuilding an important component of peacebuilding. The improvement capacity for peacebuilding, in 2005 UN Commission on peacebuilding was also established. ${ }^{i}$ In 2008, the UN under the "Capstone doctrine, re-confirmed and provided an understanding of the possible mechanisms that may be implemented by practitioners in implementing the three primary peacekeeping principles introduced by the UN namely; impartiality and non-use of force, consent and defense. Thus, the Capstone doctrine comprehends the fact that a larger component of the peace process involves the operations of the UN Peacekeeping mission (UN Peacekeeping Operations Capstone Doctrine, 2008). The Peacebuilding Fund which was established in 2005, is largely known to have increased in strength arising from the independent reviews of the fund in 2009 and by the donors in 2011, 2012 and 2013 consecutively as well as by the UN in $2013^{\mathrm{ii}}$. UN reviewed Peace Building Architecture in 2014, they planned to review again five years after the first General Assembly (Hearn, Bujones, \& Kugel, 2014).

\section{HISTORICAL VIEW OF JAPAN'S PEACEBUILDING DIPLOMACY}

Japan attempted to project the impression of a democratic country by implementing its Peace Constitution in 1946, granting itself only defensive capabilities and avoiding becoming a military power.By the end of the 1980's, Japan's new enthusiasm for an international peace and security cooperation policy was due to the international community's cooperation. In May 1988, Prime Minister Noboru Takeshita declared a new foreign policy for Japan, reflecting the contribution of Japan to the world. (Sudo, 1989). In the 1990s, Japan sought to coordinate its actions with UN conflict prevention efforts. The 1992 International Peace Cooperation Act (IPCA) allowed the Japanese SelfDefense Forces (JSDF) to participate in UN peacekeeping operations (UNPKO). The IPCA, also known as the peacekeeping operations (PKO) Law, allowed the JSDF to be dispatched abroad in a human contribution to the military sector. The full-fledged international peace and security activities of Japan started with Cambodia 's involvement in UN peacekeeping operations in 1992 (MOFA, 2014). Japan also highly appreciated the G8 conflict prevention efforts and played a leading role in them. Significant attention was paid to conflict prevention at the 25 th Cologne Summit in 1999 and one of the important issues posed by the G8 was a holistic approach to conflict prevention at the Kyushu-Okinawa Summit hosted by Japan in the year 2000. The agreement was reached at the 'G8 Miyazaki Conflict Resolution Measures' G8 Conference of Foreign Ministers, chaired by Japan. Under the heading of the Miyazaki Initiatives, the Japanese government also released "Action from Japan on Conflict and Progress, Japan Progress Cooperation for Conflict Prevention" (MOFA, 2000).

Japan implied a new, integrated approach to peace- making, peace- keeping and (post- conflict) peacebuilding in response to the UN Agenda for Peace and Brahimi Report with its own brand of "consolidation Peace" (MOFA, 2006). In 2001, Japan amended the International Peace Cooperation Act, removing restrictions on Peace Keeping Operations (PKO) activities under existing law and allowing activities that were a normal part of the responsibilities 


\section{Nirmali Wijegoonawardana}

of the peacekeeping force, as well as expanding the range of permitted arms defense activities (MOFA, 2002). Accordingly, these steps addressed the loosening of the problems that a peacekeeping force might expect to face as part of its obligations. In addition, a major revision of defensive plans was conducted in 2004, which acknowledged how the capacity of the Self-Defense Forces (SDF) to effectively engage in international peace cooperation activities could independently contribute to international security. During this timeframe, SDF were active and coordinated in response to the massive Sumatra earthquake in the Indian Ocean in December 2004, which resulted in several hundred thousand lives being lost. The SDF Act was revised again in 2007 and the status of ministry of the SelfDefense Agency was raised, while international peace cooperation activities were formally part of the responsibilities of the SDF. The new Central Readiness Force (CRF) was established under the direct purview of the Minister of Defense in the ground SDF in 2007 to immediately respond to the entire gamete of international peace cooperation activities as well as to the transportation of citizens of Japan residing overseas in the event of disasters or disruptions in other countries or other emergencies (MOD, 2007). Japan has demonstrated its human capacity to contribute to the international community.

Furthermore, in 2002, Prime Minister Koizumi also stated Japan's policy of reinforcing aid to conflict- affected countries through cooperation in establishing strong peace and nation- building, making thus paving the path for such pillars to be the cornerstone of international cooperation. The Akashi Commission has been set up under the leadership of Prime Minister Koizumi to develop more robust peace cooperation efforts. Japan has been endorsing the method of "consolidation of peace" and "nation-building" since the month of May of the year 2002, when Prime Minister Junichiro Koizumi first suggested this notion in a policy speech which he made in Sydney, Australia (MOFA, 2004). In 2003, the Japanese Government revised the overall structure of the Official Development Assistance (ODA) to address existing global concerns, such as poverty reduction and sustainable development, and also added peacebuilding (MOFA, 2014). Furthermore, ODA shall support the promotion of the humanitarian and restoration efforts and the peace process such as the support of refugees and the reconstruction of a underpinning for everyday life; the disarmament and demobilization of soldiers and their return to society (DDR) and the collection and destruction of arms, including the removal of landmines; to protect national stability and civil peace. Japan concentrated on Asia and led the G8 to support concerns such as the police and the return of former soldiers to the society of Afghanistan. Japan has also been involved in nation-building cooperation in East Timor, a conflict of independence and a ceasefire in the secession in Aceh, Indonesia, and the promotion of peace amongst antigovernment Muslim forces in Mindanao located in the south of Philippines, and promoting restoration and peacebuilding in Sri Lanka (MOFA,2014).

Under the ODA Policy on Conflict and Development and Development Cooperation Charter in February, 2015 under the Priority Policies refer that,

"Peace, stability and security are prerequisites for nation-building and development. Accordingly, Japan will comprehensively address a wide range of factors causing conflict and instability, including poverty. It will also provide seamless assistance for peacebuilding from conflict prevention, emergency humanitarian assistance in the conflict situation, and promotion of conflict termination to emergency humanitarian assistance and assistance for recovery, reconstruction, and development in the post-conflict stage. Such assistance will address a range of needs such as; humanitarian assistance for refugees and internally-displaced persons; protection and participation of women and the socially vulnerable; reconstruction of social and human capital; the restoration of governance functions based on a trusting relationship between the government and the public; the removal of landmines and unexploded ordnance and the collection of small arms; and the restoration of public order (MOFA, $21^{\text {st }}$ February 2017)."

Above priority policies reflect Japan`s peacebuilding efforts in post- conflict societies. Japanese Prime Minister Shinzo Abe at the Conference on Peacebuilding, National Reconciliation and Democratization in Asia took place on 20 June 2015, highlighted the continued commitment of Japan to democracy and peace in Asia as part of its "Proactive Contribution to Peace" policy (MOFA,2015). Foreign Minister Fumio Kishida, who delivered a keynote speech, entitled" A Peace- Loving Nation Walking with Asia." He outlined Japan's philosophy and approach to peacebuilding and described the efforts it has made as a peace- loving nation in many parts of Asia for 70 years and further, he stated that, "I will make the contribution to peacebuilding, national reconciliation, and democratization in Asia a new pillar of my 'Kishida-Diplomacy" (MOFA, 2015).

Since the 1980s, Japan's peace-building diplomacy has been very significant in contributing towards international peace and security cooperation. Japan has suggested a new, integrated approach to peace-making, 
Peacebuilding Practices of Japan: Lessons from Sri Lanka

peace-keeping and peace-building with its own 'consolidation peace' brand in post-conflict societies in response to the UN Peace Agenda.

\section{JAPAN'S PEACEBUILDING PRACTICE IN SRI LANKA}

On 16 May 2009, the government of Sri Lanka declared victory over nearly three decades of violent ethnic conflict, which ended in 2009 with a military victory. Conflict started between majority Sinhala and minority Tamil community. The root causes originate from the colonial period and conflict intensified as a form of violence during the 1980s. The escalation of the conflict and mounting violence is evident until May 2009. However, Sri Lankan government and Liberation Tigers of Tamil Ealam (LTTE) as a representative for Tamil community was able to signed a ceasefire agreement in 2002 and after several rounds of peace talks in 2005 it collapsed. During the period 2002-2005 peace talks was supported by several international community including Japan. War ended through a military victory of the government of Sri Lanka in May 2009 at the cost of thousands of lives, disappearances and internal displacement of people with denial of allegations of human rights violations during the war by the international communities. However, since 2009 until present, Sri Lanka is in the process of reconciliation to established sustainable peacebuilding with assistance of international community. The journey of peacebuilding, Japan has become the major contributor of Sri Lanka.

Japan and Sri Lanka diplomatic relations has a record of history over 65 years. History of Japan and Sri Lanka diplomatic bilateral relations revisited by Japanese Foreign Minister Taro Kono on Official arrival in $4^{\text {th }}$ of January 2018 Colombo in Sri Lanka. Foreign Minister stated that,

"The friendly relationship between Japan and Sri Lanka originated after the speech made by the then Finance Minister J.R. Jayewardene at the San Francisco Peace conference in 1951 where he defended sovereign rights of Japan. The Japanese still remember that this speech supported Japan's return to the international society after the WWII (Daily News, 05th January 2018)."

Diplomatic Relations were established between Sri Lanka and Japan as soon as the Peace Treaty was signed. During the months February 1952 and in May 1953 Sri Lanka established an embassy in Tokyo and a Japanese Mission was set up in Colombo.

Japan first peacebuilding initiative started in Sri Lanka in 2002, which Norway facilitated ceasefire agreement. On 25 October 2002, the Koizumi government appointed Yasushi Akashi as the special representative of the Japanese government for peace-building in Sri Lanka. Prior to his mission to Sri Lanka, Akashi held positions at the headquarters of the United Nations Secretariat in New York as Under Secretary-General for Public Knowledge, Under-Secretary-General for Disarmament Affairs and Under-Secretary-General for Humanitarian Affairs and Emergency Relief Coordinator. He has been personally involved in mediation between 2002 and 2009, the government of Sri Lanka and the LTTE assisted the international community in the Sri Lankan peace process. Akashi was also the chief advisor to the Urgent Humanitarian and Recovery Needs Subcommittee of the North and East (SIHRNN). Akashi visited the country at least 30 times as a peace envoy, and even after the war he visited Sri Lanka to promote reconciliation (MOFA: 2018). Yasushi Akashi was as a peace advisor to Sri Lanka, in his visit November 2018 he remarked that;

"I regret one promise I made on the occasion when I undertook my mission for peace-building and reconciliation in Sri Lanka. During my first visit, I was invited to visit artistic and historical sites in Sri Lanka and I said that I would very much like to visit these sites. However, I said I would visit these places after I accomplished my mission of peace. So, when Ranil Wickremesinghe was the Prime Minister in 2002, for the first time, he took me to see some of these historical sites which were impressive, but I declined to spend more time visiting them until I had accomplished my mission. That moment of complete accomplishment never came. Much has been achieved and lots of efforts have been undertaken by Sri Lanka since ending the war during the tenure of President Mahinda Rajapaksa in 2009, to make peace an actual reality. But still there is more to do. So, I wonder at what moment I will realise my dream (Daily News, 21 st November 2018)."

Most importantly Japan's approach towards peace is reflected in recent comments made by Yasushi Akashi. According to Lam (2004) Akashi sought foreign support from the United Nations for the Sri Lankan peace process (Lam, 2004, p.10). Japan hosted a sixth round of peace talks between the government of Sri Lanka and the LTTE in Hakone from 18 to 21 March 2003. On 9 and 10 June 2003, the Ministry of Reconstruction organized the Sri Lanka Conference in Tokyo, attended by 51 countries and 22 international organizations. The international community 
Nirmali Wijegoonawardana

displayed a clear and unanimous commitment at the Tokyo Conference to support the Sri Lankan peace process and declared its intention to provide $\$ 4.5$ billion in assistance to all of Sri Lanka, including the northern and eastern regions, over the next four years. On behalf of Japan, Yoriko Kawaguchi, Minister of Foreign Affairs, announced that Japan had in place plans to provide up to $\$ 1$ billion in assistance over the next three years while reviewing the initiative progress of peace in Sri Lanka (ODA white paper, 2003).

It is vital to note that at the Tokyo Conference, The Tokyo Declaration on the Reconstruction and Development of Sri Lanka was adopted. This declaration stated, inter alia, that the international community will oversee and evaluate growth in the peace process in view of the link between donor support and growth in the peace process. In the future, Japan expects to continue to contribute actively to the peace process in Sri Lanka in accordance with the ideologies set out in the Tokyo Declaration and hand in hand with the countries and organizations concerned, specially the Tokyo Conference co- chairs (ODA white paper, 2003). However, LTTE boycotted the Tokyo conference and Akashi commented on recent visit to Sri Lanka and he added:

"I profoundly regret that Prabhakaran missed all the opportunities given to him. The Tokyo conference was a great opportunity, and after the Indian Ocean tsunami, then President Chandrika Bandaranaike Kumaratunga came up with a rebuilding programme in which the LTTE was invited to participate. But he shut the door at that time as well. There were other occasions where Prabhakaran told Northern Tamils not to participate in elections. He lost so many opportunities for peace and peaceful negotiations (Daily News, 21st November 2018)."

Akashi' s comments reflect that, there was abundant expectation from Japan at the beginning but things began to gradually worsen. Paramount donors ranging from Japan projected to comprehend the "dividends of peace" to raise the peace process. However, they ultimately could not find the necessary space and time to pursue this course fully (Shinoda, 2009). The peace process was futile and the political environment hastily changed in Sri Lanka.

\subsection{TSUNAMI AND DEVELOPMENT ASSISTANCE}

The Japan International Cooperation Agency (JICA) have put out the "Recovery, Rehabilitation and Development Project in Tsunami Affected Area" project in Sri Lanka. Japan on the 31 st of December of the year 2004, just after the Tsunami disaster, graciously donated much needed emergency aid materials including mats, blankets, generators, tents, water purification systems and water tanks worth over Rs.29.6 million. Within the period spanning from the $29^{\text {th }}$ of December of the year 2004 to the $15^{\text {th }}$ of January of the year 2005 the JDR medical team was dispatched by the Japanese government through JICA to administer an emergency medical clinic in Sainthamaruthu in Ampara district. The government of Japan during the month of January in the year 2005 further provided US\$ 80 million worth of Non-Project Grant Aid to support relief, reconstruction activities and rehabilitation in the areas affected by the Tsunami. Within the period of $17^{\text {th }}$ January to $9^{\text {th }}$ February 2005, JICA deployed a Tsunami Disaster Needs Assessment Mission, consisting of 16 members, the mission of this team being, to carry out an overall assessment on necessary requirements in the areas affected by Tsunami.

Since the beginning of the Sri Lankan peace process, the Government of Japan and other Non-Governmental Organizations (NGO) have been actively contributing to the implementation of humanitarian assistance and peacebuilding programs in the North, East and South of Sri Lanka affected by the war. The JICA annual report stated that,

"Since the conflict was suspended, JICA has continued to support war-affected people and refugees. JICA makes the utmost efforts in these projects to empower communities in the areas affected by the conflict. Together with direct support for residents, JICA provides training for administrators who deal with residents' groups to empower communities and municipalities so that they can resolve various problems and issues that they face through their own wisdom and power. Four years after the conflict was suspended, the peace talks between the government and the LTTE are in a static state; however, the life of the people in the conflict affected areas is steadily improving. Desires not to restart the war and to improve the standard of living are steadily growing in the hearts and minds of the people. Meeting face-to-face with the people, JICA will actively continue to implement its projects to empower communities (JICA annual report, 2006)."

Japan started development assistance project hoping the end results as peace in Sri Lanka. Under the support of social capital JICA implemented in 2004- 2007 a project called Mannar district Rehabilitation and Reconstruction over Community Approach Project (MANRECAP) making consideration for reconciliation and coexistence in northern province in Sri Lanka. Under the Japanese ODA loan programme, the Vavuniya-Kilinochchi Transmission 
Line programme in 2005 and the Japanese Pro-Poor Eastern Infrastructure Growth Project in 2006. Agriculture and Rural Development Technical Cooperation Project for Restoration and Reconstruction over Group Approach in Trincomalee (TRINCAP) 2005-2009 Eastern Province of Sri Lanka.

Following the assistance received, Japan`s hope was that people will benefit candidly from recovery and development plans, develop their livelihoods, reach sustainable peace through reconciliation efforts and reach selfreliance and socio- economic growth. Immediately after the end of the ethnic conflict of by the military victory, Japan begins to provide their assistance for reconciliation and peacebuilding.

\subsection{JAPAN'S NORTHERN AND EASTERN ASSISTANCE FOR PEACE AND DEVELOPMENT SINCE 2009}

The military conflict ended in May 2009, a new government led by President Mahinda Rajapaksa was inaugurated following the January 2010 presidential election. The joint statement by UN Secretary - General Ban Ki - Moon and the government of Sri Lanka at the end of the visit of the UN Secretary - General to Sri Lanka on 23 May 2009, Sri Lanka entered into a new post -conflict start and agreed that it would tackle the aspirations and grievances of all communities and work towards a lasting political solution was essential to ensure socio-economic development in the long term. After this development, Japan focuses its support in Sri Lanka on peacebuilding and reconstruction as well as medium- and long- term development visions. Japan has fully supported the peace process, as it confidently trusts that peace and reconciliation are prerequisites for Sri Lanka's sustainable development and success.

\subsection{IMMEDIATE ASSISTANCE TO CONFLICT AFFECTED AREAS}

After ending the war in May 2009, Sri Lanka sought further assistance from Japan for peacebuilding support, including assistance for internally displaced persons. The Program for Human Resource Development in Asia for Peacebuilding is a program which wishes to ripen Japanese and other Asian civilian personnel in the turf of peacebuilding. The International Office for Migration (IOM) Sri Lanka, engrossed in the project support internally displaced persons (IDPs) in Vavuniya, which the Government of Japan has funded one million US dollars to Sri Lanka and Japanese nationals were also worked in the IOM. In October 2009, Sri Lankan government announced the return of more than 40,000 IDPs and Japan`s government hoped that the Sri Lankan government will fast-track early resettlement of IDPs to their villages (MOFA, 2009).

The Government of Japan decided to send to Yasushi Akashi on 15 ${ }^{\text {th }}$ June 2010, Representative of the Government of Japan for Peacebuilding, Rehabilitation and Reconstruction in Sri Lanka. Akashi was focused on early resettlement of IDPs as well as swift progress in political processes for national reconciliation toward the formation of long-lasting peace. Furthermore, Minister for Foreign Affairs Katsuya Okada, showed the significance of the government of Sri Lanka to fulfill accountability on human rights issues, and proposed resolving the issues in cooperation with the United Nations (MOFA, 2010).

Japan also, was a key donor to Sri Lanka's de-mining operations to quicken the return and resettlement of IDPs and to ease the resumption of agriculture and livelihood. In 2010, Japan has provided US\$1.6 million for de-mining projects in Mannar, Kilinochchi and Jaffna in severely war affected areas in northern Sri Lanka (MOFA, 2010). The aid towards de-mining also adds to creating novel employment opportunities for residents in these areas. There is an ongoing program in the field of human resources development to improve the capacity of local authorities by training 3,000 staff from the Northern and Eastern Provincial Councils. Similarly, several public officials from the North and the East have been involved in higher studies in the fields of post- conflict reconstruction and peace building under the Japan funded scholarship programme.

In 2011, in response to the devastating floods caused by the extreme heavy rain in conflict-affected areas of Sri Lanka, the Government of Japan agreed to extend emergency relief goods worth 20 million Japanese Yen to Sri Lanka through the JICA at the request of its Government.

Japan welcomes the fact that the first elections to the Northern Provincial Council in Sri Lanka were held largely in a peaceful manner on 21 September 2013. This is a major step forward in the process of national reconciliation after many years of conflict. 
Nirmali Wijegoonawardana

\subsection{PROACTIVE CONTRIBUTION TO PEACE AND MARITIME INTEREST}

Japanese Prime Minister Abe visited Sri Lanka 2014 and he expressed his intention to further strengthen the bilateral cooperative relationship by developing traditionally friendly relations to "A New Partnership between Maritime Countries" (MOFA, 2014). He also explained that Japan's Proactive Contribution to Peace and expressed his intention to continue to cooperate toward the regional cooperation in South Asia and strengthening connectivity. Prime Minister Abe mentioned that Japan has decided to provide yen loan amounting up to 13.7 billion yen for Digitalization of Terrestrial Television Broadcasting Project and to advance cooperation in the field of transportation infrastructure (JICA, 2014). Prime Minister Abe focused the efforts of Sri Lanka toward national reconciliation including the holding of elections in Northern Province and conveyed Japan's intention to be involved in this matter to encourage positive efforts.

State Minister for Foreign Affairs Minoru Kiuchi visited newly elected President March 2015, he acclaimed that the first-hand government was fostering dialogue with the international community while improving local methods, and articulated Japan's aim of supporting new government's positive steps towards reaching national reconciliation. State Minister Kiuchi delivered Japan's purpose of providing new yen loans amounting to approximately 70 billion Yen (MOFA, 2015).

Prime Minister Shinzo Abe stated at the G7 summit in 2016 that Japan would also strengthen cooperation with Sri Lanka through the initiative "Expanded Partnership for Quality Infrastructure." Prime Minister Abe expressed his intention to provide ODA loans, which amount to approximately 38 billion yen, for construction of transmission lines in the North Central and Eastern Provinces and water supply facilities in the North Central Province, in order to further promote peace through socio-economic development of Sri Lanka. The transmission line construction project will allow the electricity produced from power plants planned by Sri Lanka in the Eastern Province to be transmitted to the city of Colombo. (MOFA:2016).

Moreover, the leaders of both countries were receptive of the first round of the Policy Dialogue of the two foreign ministries at the Senior Official Level. The initial Sri Lanka-Japan Dialogue on Maritime Security, Safety and Oceanic Issues in January 2016 which was held in Colombo, in which the two maritime states undertook to re-assess the importance of preserving the freedom of the high seas and maritime order built on the rule of law. Both leaders in a bid to further solidifying maritime cooperation between the two countries, acknowledged the significance of the firm development of the Project for Maritime Safety Capability Improvement (worth approximately 1.8 billion yen), that comprises the inclusion of two patrol vessels. Prime Minister Abe also voiced his intent of sending missions to survey and analyze the needs for hub development of the north port of Colombo and its adjacent areas, as well as the development of the port of Trincomalee (MOFA, 2016).

In May 2016, Prime Minister Abe expressed Japan's continued support for efforts of the current national reconciliation process in Sri Lanka, and received the trade of notes regarding the Project for the Establishment of Research and Training Complex at the Faculty of Agriculture, University of Jaffna approximately 1.7 billion yen. (MOFA, 2016).

Minister for Foreign Affairs Taro Kono, in January 2018 visited Sri Lanka and explained that presently Japan and Sri Lanka are important economic and trading partners with annual bilateral trading exceeding 100 billion Japanese Yen and providing traded notes regarding the provision of a loan up to 10.639 billion Yen (MOFA, 2018), He stated further, that, main purpose of his visit to Sri Lanka is that,

"Both Japan and Sri Lanka, as maritime nations, can enjoy development and prosperity from the free and open Indo-Pacific and thus bear responsibilities in realizing it. Japan is determined to further promote peace and prosperity in the region together with Sri Lanka by enhancing connectivity through quality infrastructure projects such as the port development as well as by strengthening for maritime safety (Daily News, 12th November 2018)."

This reflects that Japan needs partnership and concrete cooperation from Sri Lanka for maritime safety in the Indo-Pacific Ocean while assisting for national reconciliation and peacebuilding.

\section{CONCLUSION}

Japan is one of the few countries to engage vigorously in UN peace diplomacy, and several UN Member States occupy high positions. In recent years, Japan has assumed its duty by actively taking part in international contributions to peace. The initial step was to pursue a systematic Japanese international peacebuilding strategy for 
conflict prevention through non-military diplomacy and the peaceful overseas allocation of the SDF. Japan considered involvement in the UN PKO to be international corporation.

Bilateralism is an important feature of Japan's strategy for peace- building involvement in Sri Lanka. The peacebuilding strategy is intertwined economic reconstruction and development assistance. Japan has many development aid tools and methods that are well suited to its peace- building objectives in Sri Lanka.

Rebuilding Sri Lanka's vulnerable state, where almost nearly thirty years of conflict, chaos and decline have led to Japan's extreme dysfunctional task. Rebuilding such a vulnerable state into a sovereign state restores peace is can't be done within a few years. The aspect of "human security" that, deals with the seriousness of life, livelihoods and dignity of people who have battled for almost three decades of conflict bring back to normalcy needs more time and serious strategies as part of government of Sri Lanka as well. Lederach (1997) stressed that a lot of different acts and methods are protected by transforming conflictual relationships into peaceful ones. In the post-Sri Lanka war, Japan's peace-building strategy was "driven by supply" rather than "driven by demand," through the economic and development process.

\section{SOURCES OF FUNDING}

This research received no specific grant from any funding agency in the public, commercial, or not-for-profit sectors.

\section{CONFLICT OF INTEREST}

The author have declared that no competing interests exist.

\section{ACKNOWLEDGMENT}

None.

\section{REFERENCES}

[1] Cousens, et al., (2001). Peacebuilding as politics: cultivating peace in fragile societies. Lynne Rienner Publishers.

[2] De Coning, C., Detzel, J., \& Hojem, P. (2008, May). UN Peacekeeping Operations Capstone Doctrine. In Report of the TfP Oslo doctrine seminar (Vol. 14).

[3] Fukuyama, F. (2005). " Stateness" First. Journal of democracy, 16(1), 84-88.

[4] Lam, P. E. (2004). Japan's peace building diplomacy in Sri Lanka. East Asia, 21(2), 3-17.

[5] Lederach, J. P. (1997). Sustainable reconciliation in divided societies. Washington, DC: USIP.

[6] Hearn, S., Bujones, A. K., \& Kugel, A. (2014). The United Nations" Peacebuilding Architecture": Past, Present and Future. New York: Center on International Cooperation.

[7] Japan International Cooperation Agency (2005) Tsunami Recovery, Rehabilitation and Development Project Retrieved from https://www.jica.go.jp/srilanka/english/office/topics/press03.html

[8] Japan International Cooperation Agency (2006). Annual Report, Priority Placed on Cooperation for Poverty Reduction and Economic Development (Asia 4) Retrieved from https://www.jica.go.jp/english/publications/reports/annual/2006/pdf/046-048.pdf

[9] Japan International Cooperation Agency (2014) Feasibility Study on Digital Terrestrial Television Broadcasting Network Project in Sri Lanka Retrieved from http://open_jicareport.jica.go.jp/pdf/12154530.pdf

[10] Ministry of Foreign Affairs of Japan (2000) G8 Miyazaki initiatives for Conflict Prevention. Retrieved fromhttps://www.mofa.go.jp/policy/economy/summit/2000/documents/initiative.html

[11] Ministry of Foreign Affairs of Japan (2002) Speech by Prime Minister Junichiro Koizumi. Retrieved from https://www.mofa.go.jp/region/asia-paci/pmv0204/speech.html

[12] Ministry of Foreign Affairs of Japan, ODA White Paper (2003) The Revision of the "Oda Charter" And Japan's New Approach. Retrieved from https://www.mofa.go.jp/policy/oda/white/2003/part1_2_1_3.html 
[13] Ministry of Foreign Affairs of Japan (2005) Statement by Prime Minister Junichiro Koizumi. Retrieved from https://www.mofa.go.jp/announce/announce/2005/8/0815.html

[14] Ministry of Foreign Affairs of Japan (2005) Japan's Official Development Assistance White Paper 2005 Retrieved https://www.mofa.go.jp/policy/oda/white/2005/ODA2005/html/honpen/hp202020400.htm

from

[15] Ministry of Foreign Affairs of Japan (2006) Japan's Support for the Consolidation of Peace in Africa Retrieved from https://www.mofa.go.jp/region/africa/ticad/peace/support.html

[16] Ministry of Defense of Japan (2007) Measures for Defense of Japan, Efforts to support International Peace $\begin{array}{lllll}\text { Cooperation } & \text { Activities } & \text { (Chapter } & 3 \text { ) } & \text { Retrieved }\end{array}$ http://www.mod.go.jp/e/publ/w_paper/pdf/2007/part3/3-3/3-3.pdf

[17] Ministry of Foreign Affairs of Japan (2009), on the End of the Civil War in Sri Lanka Retrieved from https://www.mofa.go.jp/announce/announce/2009/5/1192009_1134.html

[18] Ministry of Foreign Affairs of Japan (2010) Japan-Sri Lanka Foreign Ministers' Meeting (Overview) Retrieved from https://www.mofa.go.jp/announce/announce/2010/7/0729_04.html

[19] Ministry of Foreign Affairs of Japan (2012) Executive Summary of the Report of the Advisory Group on International Cooperation $\quad$ for $\quad$ Peace. Retrieved from https://www.mofa.go.jp/policy/un/pko/report0212.pdf

[20] Ministry of Foreign Affairs of Japan (2014) Japanese Participation in UN Peacekeeping Cambodia Retrieved from https://www.mofa.go.jp/policy/un/pko/pamph96/02_2.htm

[21] Ministry of Foreign Affairs of Japan (2014) Revision of Japan's Official Development Assistance Charter Retrieved from https://www.mofa.go.jp/policy/oda/reform/revision0307.html

[22] Ministry of Foreign Affairs of Japan (2014). Final Statement on the High-Level Seminar on Peacebuilding, National Reconciliation and Democratization in Asia. Retrieved from https://www.mofa.go.jp/a_o/rp/page24e_000089.html

[23] Ministry of Foreign Affairs of Japan (2014) A New Partnership between Maritime Countries Retrieved from https://www.mofa.go.jp/files/000051016.pdf

[24] Ministry of Foreign Affairs of Japan (2015) State Minister for Foreign Affairs Kiuchi's Visit to Sri Lanka Retrieved from https://www.mofa.go.jp/s_sa/sw/lk/page3e_000309.html

[25] Ministry of Foreign Affairs of Japan (2015) Final Statement on the High-Level Seminar on Peacebuilding, National Reconciliation and Democratization in Asia Retrieved from https://www.mofa.go.jp/a_o/rp/page24e_000089.html

[26] Ministry of Foreign Affairs of Japan (2015) Final Statement on the High-Level Seminar on Peacebuilding, National Reconciliation and Democratization in Asia. Retrieved from https://www.mofa.go.jp/a_o/rp/page24e_000089.html

[27] Ministry of Foreign Affairs of Japan (2016) Official Development Assistance (ODA) Retrieved from https://www.mofa.go.jp/policy/oda/white/2016/html/honbun/b2/s2_3_3.html

[28] Ministry of Foreign Affairs of Japan (2016) Advisory Group on International Cooperation for Peace Retrieved from https://www.mofa.go.jp/policy/un/pko/report0212.pdf

[29] Ministry of Foreign Affairs of Japan (2016) Advanced Partnership towards Growth and Prosperity Retrieved from https://www.mofa.go.jp/s_sa/sea2/tp/page4e_000390.html

[30] Ministry of Foreign Affairs of Japan (2016) Media Statement Japan-Sri Lanka Summit Meeting Retrieved from https://www.mofa.go.jp/files/000160708.pdf

[31] Ministry of Foreign Affairs of Japan (21st February,2017) Peacebuilding Assistance Japan's Action Retrieved from https://www.mofa.go.jp/policy/oda/sector/conflict/action.html

[32] Ministry of Foreign Affairs of Japan (2018). Japan's Contribution to UN Peacekeeping Operations (PKO) (Archives)Retrieved from https://www.mofa.go.jp/policy/un/pko/archive.html

[33] Ministry of Foreign Affairs of Japan (2018) Japan-Sri Lanka Relations (Archives)Retrieved from https://www.mofa.go.jp/region/asia-paci/srilanka/archives.html

[34] Ministry of Foreign Affairs of Japan (2018) Japan-Sri Lanka Summit Meeting Retrieved from https://www.mofa.go.jp/s_sa/sw/lk/page4e_000781.html

[35] Ministry of Defense of Japan (n.d.) The GSDF Central Readiness Force (No 6) Retrieved from http://www.mod.go.jp/e/jdf/pdf/jdf_no06c.pdf 
[36] Shinoda, H. (2009). Implementing Peace through the Imposition of Rule of Law: Reevaluating Peace-building Strategies in Bosnia and Herzegovina Ten Years after the Dayton Peace Agreement. International Studies Association

[37] Somarathna, R. (2018, November12th) Japan to enhance defence cooperation. Daily News Retrieved from, http://dailynews.lk/2018/11/12/local/168203/japan-enhance-defence-cooperation

[38] Somarathna, R. (2018, November21st) Prabhakaran Shut Door to Peace - Akashi Daily News Retrieved from, http://www.dailynews.lk/2018/11/21/features/169037/prabhakaran-shut-door-peace-akashi

[39] Somarathna, R. (2018, January 5th) Diplomatic Peace-Building Daily News Retrieved from http://www.dailynews.lk/2018/01/05/features/138998/diplomatic-peace-building

[40] Sudo, S. (1989). Japan's role in the context of the emerging Asia-Pacific world. Southeast Asian Affairs, 16, 51.

[41] United Nations (2000) Brahimi Report, Report of the Panel on United Nations Peace Operations Retrieved from http://www.un.org/en/events/pastevents/pdfs/Brahimi_Report_Exec_Summary.pdf)

\section{Notes}

i The Peacebuilding Commission was established on 20 December 2005 by resolutions of the General Assembly (resolution 60/180) and the Security Council (resolutions 1645 (2005) and 1646 (2005)).

ii See for more details: Nicole Ball, Mariska van Beijnum (2009), Review of the Peacebuilding Fund. Available at: http://www.clingendael.nl/sites/default/files/20090604\%20 PBF_Review.pdf; DFID Multilateral Aid Review, PBF, 2011, 2013; Australia Multilateral Aid Review, PBF 2012; 